\title{
Performance of Different Guava Cultivars under the Subtropical Condition of Himachal Pradesh
}

\author{
Rashmi Kumari, B. S. Thakur, Babita* and Rimpika
}

Dept. of Fruit Science Dr. Yashwant Singh Parmar University of Horticulture and Forestry, Nauni, Solan, Himachal Pradesh (173 230), India

\section{Article History}

Manuscript No. AR1515

Received in $7^{\text {th }}$ January, 2016

Received in revised form $14^{\text {th }}$ March, 2016

Accepted in final form $5^{\text {th }}$ April, 2016

\section{Correspondence to}

*E-mail: babitasoniuhf@gmail.com

\section{Keywords}

Guava, cultivars, hybrids, vegetative growth, flowering, fruiting, yield

\begin{abstract}
The present investigation was carried out at the Horticultural Regional Research Station, Dhaulakuan, (Sirmour District) of Dr. Yashwant Singh Parmar University of Horticulture and Forestry, Nauni, Solan during the year 2011-12. The trial was laid out on bearing guava trees in a Randomized Block Design. The treatments comprised of six cultivars/hybrids of guava viz., Hybrid-1, Hybrid-3, Allahabad Safeda, Hisar Safeda, L-49 and Lalit. In the present study, among tress characteristics, the highest plant height $(3.30 \mathrm{~m})$, trunk girth $(5.28 \mathrm{~cm})$ and shoot extension $(24.90 \mathrm{~cm})$ in Allahabad Safeda which was significantly higher than other cultivars. Flowering characteristics like duration of flowering (41 days) was also observed maximum in Allahabad Safeda. Cultivar Hisar Safeda was earliest to bloom ( $20^{\text {th }}$ April) followed by Lalit (21 $1^{\text {st }}$ April), Hybrid-1 (22 ${ }^{\text {nd }}$ April) and Hybrid-3 (23 $3^{\text {rd }}$ April) and also earliest in full bloom ( $26^{\text {th }}$ May) which was followed by again followed by Lalit and Hybrid-1(28 ${ }^{\text {th }}$ May). The longest maturity period (129 days) were also reported in Allahabad Safeda and Hybrid-1 was earliest in maturity (115 days) followed by Lalit (117 days) and Hybrid-3 (118 days). However, fruiting characteristics viz., maximum fruit set i.e. $73.40 \%$, minimum fruit drop i.e. $42.80 \%$ and the highest yield of $10.20 \mathrm{k} \mathrm{tree}^{-1}$ was recorded in cv. L-49. On the basis of overall performance it was found that Allahabad Safeda was found most promising cultivar for subtropical condition of Himachal Pradesh.
\end{abstract}

\section{Introduction}

Guava (Psidium guajava L.) is native to northern South America and widely distributed in the tropical regions of America (Risterucci et al., 2005). It belongs to the Myrtaceae family, comprising more than 70 genera and 2,800 species. It is the fifth most important fruit crop of India and commonly, it is known as "apple of tropics". The fruit occupies an important place in the horticultural wealth of our nation and ranks sixth with respect to area and production. In India, it occupies nearly 275 thousand ha with production of 3, 795 thousand $\mathrm{mt}$ (NHB, 2014). In Himachal Pradesh, it is cultivated in the area of 2 , 233 hectares with production of 2, $502 \mathrm{mt}$ (Anonymous, 2014). Guava is popular among the people of all social strata due to its comparative low price than some other fruits, nourishing value and good taste. It is a rich source of vitamin C (260 mg $100 \mathrm{~g}^{-1}$ ) which is second after aonla (600 mg $\left.100 \mathrm{~g}^{-1}\right)$. It is also rich in pectin, fare source of vitamin A, fibers and good source of calcium and phosphorus. The presence of Vitamin $\mathrm{C}$ and other phytonutrients, such as caretenoids and polyphenols, in guava has leads to it being an effective antioxidant. Guava has general haemostatic properties and can be used for treating bleeding nose, gums and minor internal hemorrhaging.

Guava produces abundant crop of better quality in areas having a distinct winter compared to tropical areas. The foothills regions of Himachal experience a distinct winter and thus offer good potential for its cultivation especially, under the changing climatic scenario. In order to find out the suitability of guava cultivation under the foothills of the state some commercial cultivars were introduced at the Regional Horticultural Research Station, Dhaulakuan from different parts of the country. Therefore, the present investigation was carried out to evaluate their performance under the subtropical condition of the Himachal Pradesh.

\section{Materials and Methods}

The investigation was carried out at Horticulture Regional Research Station, Dhaulakuan of Dr. Yashwant Singh Parmar 
University of Horticulture and Forestry, Nauni, Solan is located between $35.5^{\circ} \mathrm{N}$ latitude and $77.5^{\circ} \mathrm{E}$ longitude at an elevation of 468 meters above mean sea level. Six years old plants of different guava cultivars/hybrids viz., Hybrid-1, Hybrid-3, Allahabad Safeda, L-49 (Sardar Guava), Hisar Safeda and Lalit were selected for the study during the year 2011-12. The trial was laid out on bearing guava trees in a Randomized Block Design. The observations in respect of the tree height, trunk girth, shoot extension growth, tree volume, fruit set, fruit drop and yield were recorded in the orchard itself.

The height of each experimental tree was measured with the help of a graduated staff from the bottom to the top of the tree at the beginning and at the end of growing season and expressed as increment in tree height in centimetres $(\mathrm{cm})$. The trunk girth of each experimental tree was measured 10 $\mathrm{cm}$ above the ground expressed as increment in trunk girth in centimetres $(\mathrm{cm})$. Shoot Extension Growth was measured by selecting five shoot randomly from all over the periphery of each experimental tree and their length was measured with a measuring tape at the end of growing season and expressed in centimetres $(\mathrm{cm})$. Volume of the canopy was calculated by using the formula given by Westwood (1993) and expressed in $\mathrm{m}^{3}$.

The data on time and duration of flowering were recorded in each cultivar under study, from the initiation of flowering to full bloom. Four representative branches well spread around the periphery of the trees were selected for each cultivar under study. The date on which more than $75 \%$ of flowers were open was considered as the time of full bloom.

Fruit set and fruit drop on four marked branches were calculated as per the method suggested by Westwood (1993).

$$
\begin{aligned}
& \text { Fruit set }(\%)=\frac{\text { Number of fruit set }}{\text { Number of flower }} \times 100 \\
& \text { Fruit drop }(\%)=\frac{\text { Total number of dropped fruits }}{\text { Total number of fruits set }} \times 100
\end{aligned}
$$

Days to maturity was recorded by counting the days from fruit setting to fruit maturity. The crop load removed from the trees during the harvesting season was recorded and the yield was expressed in Kilograms (k).

\section{Results and Discussion}

\subsection{Tree Characteristics}

It is revealed from the study that the tree height varied significantly among different cultivars/ hybrids evaluated under the subtropical condition of Himachal Pradesh. The maximum tree height $(3.30 \mathrm{~m})$ was recorded in Allahabad Safeda, which was statistically at par with Hisar Safeda (2.99 m) and Hybrid-1
$(2.93 \mathrm{~m})$. The minimum tree height $(2.42 \mathrm{~m})$ was recorded in Lalit followed by L-49 (2.61 m) and Hybrid-3 (2.74 m) and was statistically at par with each other (Table 1). The results are in line with Dubey et al. (2002), who recorded maximum plant height in cv. Allahabad Safeda at Sabour, Bihar conditions. The results are also in conformity with the findings of Singh et al. (2011), who obtained highest plant height in cv. Allahabad Safeda (4.85 m) at Vindhya region of Madhya Pradesh.

The maximum trunk girth $(5.28 \mathrm{~cm})$ was recorded in the cultivar Allahabad Safeda and was significantly higher than all other cultivars. The minimum trunk girth $(3.92 \mathrm{~cm})$ was recorded in Lalit which was significantly lower than all other cultivars (Table 1). A similar trend was observed by Reddy et al. (1999) studied the performance of six guava cultivars for vegetative growth and observed maximum trunk girth (35.61 $\mathrm{cm}$ ) in Allahabad Safeda as compared to other guava cultivars. Marak and Mukunda (2007), who recorded maximum tree girth in cv. Allahabad Safeda $(6.00 \mathrm{~cm})$ under Bangalore conditions. The cultivar L-49 had significantly higher tree volume (20.99 $\left.\mathrm{m}^{3}\right)$, which was followed by Hybrid-3 $\left(17.68 \mathrm{~m}^{3}\right)$ and Hisar Safeda $\left(16.77 \mathrm{~m}^{3}\right)$.The minimum tree volume $\left(10.19 \mathrm{~m}^{3}\right)$ was recorded in Lalit and was significantly lower than all other cultivars (Table 1). The similar results were obtained by Reddy et al. (1999) who reported maximum tree volume $\left(135.7 \mathrm{~m}^{3}\right)$ in L-49 compared to other guava cultivars under rainfed subhumid region of Chhotanagpur Plateau. A similar trend was observed by Dhaliwal and Dhillon (2003), who also reported maximum tree volume $\left(81.8 \mathrm{~m}^{3}\right)$ in guava cv. L-49 under Ludhiana conditions. The highest plant height $(4.85 \mathrm{~m})$, stem girth $(49.25 \mathrm{~cm})$, cross trunk section area $\left(198.77 \mathrm{~cm}^{2}\right)$, tree volume $\left(96.35 \mathrm{~m}^{3}\right)$ was observed in Allahabad Safeda under Vindhya region of Madhya Pradesh by Singh et al. (2011).

The data on shoot extension growth of different cultivars/

Table 1: Growth characters of different cultivars/hybrids of guava

\begin{tabular}{lcccc}
\hline $\begin{array}{l}\text { Cultivar/ } \\
\text { Hybrid }\end{array}$ & $\begin{array}{c}\text { Tree } \\
\text { height } \\
(\mathrm{m})\end{array}$ & $\begin{array}{c}\text { Trunk } \\
\text { girth } \\
(\mathrm{cm})\end{array}$ & $\begin{array}{c}\text { Tree } \\
\text { volume } \\
\left(\mathrm{m}^{3}\right)\end{array}$ & $\begin{array}{c}\text { Shoot extension } \\
\text { growth }(\mathrm{cm}) \\
\text { Shoot extension } \\
\text { growth }(\mathrm{cm})\end{array}$ \\
\hline Hybrid-1 & 2.93 & 4.66 & 15.81 & 20.75 \\
Hybrid-3 & 2.74 & 4.38 & 17.68 & 18.80 \\
Allahabad & 3.30 & 5.28 & 15.29 & 24.90 \\
Safeda & & & & \\
L-49 (Sardar & 2.61 & 4.10 & 20.99 & 13.75 \\
Guava) & & & & \\
Hisar Safeda & 2.99 & 4.44 & 16.77 & 13.45 \\
Lalit & 2.42 & 3.92 & 10.19 & 16.25 \\
CD $(p=0.05)$ & 0.40 & 0.15 & 1.85 & 3.69 \\
\hline
\end{tabular}


hybrids under study presented in (Table 1). reveals that significant variation exist among different cultivars. Allahabad Safeda recorded the maximum shoot extension growth (24.90 $\mathrm{cm})$, which was significantly higher than other cultivars. The minimum shoot extension growth $(13.45 \mathrm{~cm})$ was recorded in Hisar Safeda closely followed by L-49 and was statistically at par with each other. Patel et al. (2011) studied variability in eleven cultivars of guava at mid hills condition of Meghalaya and observed maximum trunk girth and shoot growth in Allahabad Safeda $(6.20,95.50 \mathrm{~cm})$ followed by L-49 $(4.42$, $65.25 \mathrm{~cm})$ and Lalit $(4.97,61.75 \mathrm{~cm})$, respectively.

\subsection{Flowering and maturity characteristics}

It was observed that flowering in different cultivars occurred during the $3^{\text {rd }}$ and $4^{\text {th }}$ week of April. Cultivar Hisar Safeda was earliest to bloom (20 $0^{\text {th }}$ April) followed by Lalit (21 ${ }^{\text {st }}$ April), Hybrid-1 (22 $2^{\text {nd }}$ April) and Hybrid-3 (23 $3^{\text {rd }}$ April), whereas L-49 was last to flower (24 $4^{\text {th }}$ April). It is apparent from the data presented in (Table 2). that full bloom in all the cultivars occurred during the last week of May and was earliest $\left(26^{\text {th }}\right.$ May) in Hisar Safeda which was followed by Lalit and Hybrid-1 (28 $8^{\text {th }}$ May). Full bloom in L-49 and Hybrid-3 was observed on $29^{\text {th }}$ and $30^{\text {th }}$ May, respectively. Whereas, the cultivar Allahabad Safeda recorded full bloom on $31^{\text {st }}$ May. The Minimum duration of flowering (36 days) was recorded in L-49, while, Hybrid-1 and Hisar Safeda took 37 days for completion of flowering which was closely followed by Hybrid-3 and Lalit (38 days).The duration of flowering was maximum (41 days) in Allahabad Safeda. Ojha et al. (1985) also recorded the longest duration of flowering in the cultivar Allahabad Safeda (32 days). Dhaliwal and Dhillon (2003) found that initiation of flowering was early in Hisar Safeda (18 ${ }^{\text {th }}$ April, 2001) and late in L-49 (Sardar) $\left(20^{\text {th }}\right.$ April, 2001).

Table 2: Flowering and days to maturity in different cultivars/ hybrids of guava

\begin{tabular}{lcccc}
\hline $\begin{array}{l}\text { Cultivar/ } \\
\text { Hybrid }\end{array}$ & $\begin{array}{c}\text { Initiation } \\
\text { of } \\
\text { flowering }\end{array}$ & $\begin{array}{c}\text { Date } \\
\text { of full } \\
\text { bloom }\end{array}$ & $\begin{array}{c}\text { Duration of } \\
\text { flowering } \\
\text { (days) }\end{array}$ & $\begin{array}{c}\text { Days to } \\
\text { Maturity }\end{array}$ \\
\hline Hybrid-1 & $22-4-2011$ & $28-5-2011$ & 37 & 115 \\
Hybrid-3 & $23-4-2011$ & $30-5-2011$ & 38 & 118 \\
$\begin{array}{l}\text { Allahabad } \\
\text { Safeda }\end{array}$ & $21-4-2011$ & $31-5-2011$ & 41 & 129 \\
$\begin{array}{l}\text { L-49 } \\
\text { Sardar }\end{array}$ & $24-4-2011$ & $29-5-2011$ & 36 & 122 \\
$\begin{array}{l}\text { Guava) } \\
\text { Hisar }\end{array}$ & $20-4-2011$ & $26-5-2011$ & 37 & 120 \\
Safeda & & & & \\
Lalit & $21-4-2011$ & $28-5-2011$ & 38 & 117 \\
\hline
\end{tabular}

It was also observed that Hisar Safeda took maximum days (39 days) for completion of flowering.

It is evident from the data depicted in (Table 2). that Hybrid-1 was earliest in maturity (115 days) followed by Lalit (117 days) and Hybrid-3 (118 days). The longest time to reach maturity was recorded in cultivar Allahabad Safeda which took 129 days. The cultivar Hybrid-1 was earliest to mature (115 days) followed by Lalit (177 days) and Hybrid-3 (118 days). The maximum time to reach maturity was observed in Allahabad Safeda (129 days). Singh (2002) reported that cultivar Hybrid-1 took (120) days to reach maturity. Srivastava and Sarivastava (1965) reported that the cultivar Allahabad Safeda reached maturity within 65-72 days from flowering under Lucknow conditions. However this variation in the time of maturity might be due to elevation site of plantation and genotypic behaviour of cultivars.

\subsection{Fruit set, fruit drop and yield}

There was a wide variation in fruit set among different cultivars. The maximum fruit set $(73.40 \%)$ was recorded in L-49 which was statistically at par with Allahabad Safeda (69.6\%) and Hybrid-3 (67.2\%). Whereas, minimum fruit set (57.40\%) was recorded in Lalit which was statistically at par with Hybrid-1 (63.6\%) and Hisar Safeda (64.2\%) (Table3). The results are in accordance with findings of Singh (2002), who studied ten cultivars of guava and reported that fruit set ranged from 48.00 to $58.90 \%$ and highest fruit set (58.90\%) was observed in Allahabad Safeda. Sharma et al. (2011) recorded highest fruit set (82\%) in cultivar Lucknow-49 under North Indian conditions. The variation in fruit set is entirely based on the genetic makeup of cultivars, pollen fertility and prevailing climatic conditions.

It is also evident from the data that fruit drop in different cultivars ranged from 42.80 to $59.60 \%$. The minimum fruit drop $(42.80 \%)$ was recorded in L-49 which was statistically at par with Hybrid-1 (44.2\%), Lalit (47.4\%) and Hisar Safeda (49.2\%). The fruit drop was maximum (59.60\%) in Hybrid-3

\begin{tabular}{lccc}
\hline $\begin{array}{l}\text { Table 3: Fruit set, Fruit drop and Yield in different cultivars/ } \\
\text { hybrids of guava }\end{array}$ & \multicolumn{3}{c}{ Frield } \\
\hline Cultivars/Hybrid & $\begin{array}{c}\text { Fruit set } \\
(\%)\end{array}$ & $\begin{array}{c}\text { Fruit drop } \\
(\%)\end{array}$ & $\begin{array}{c}\text { Yield } \\
\left(\mathrm{k} \mathrm{Plant}^{-1}\right)\end{array}$ \\
\hline Hybrid-1 & 63.6 & 44.2 & 5.65 \\
Hybrid-3 & 67.2 & 59.6 & 6.73 \\
Allahabad Safeda & 69.6 & 55.8 & 9.46 \\
L-49 (Sardar & 73.4 & 42.8 & 10.20 \\
Guava) & & & \\
Hisar Safeda & 64.2 & 49.2 & 7.92 \\
Lalit & 57.4 & 47.4 & 7.68 \\
CD $(p=0.05)$ & 9.1 & 9.3 & 1.3 \\
\hline
\end{tabular}


followed by Allahabad Safeda (55.8\%) and was statistically at par with each other (Table 3). Similar results were obtained by Sharma et al. (2011), who reported minimum fruit drop in cultivar Lucknow-49 in north Indian conditions.

The cv. L-49 recorded the highest yield of $10.20 \mathrm{k} \mathrm{tree}^{-1}$ which was statistically at par with Allahabad Safeda $\left(9.46 \mathrm{k} \mathrm{tree}^{-1}\right)$ and was significantly higher than all other cultivars (Table 3 ). Singh (2003) evaluated seven cultivars of guava and reported highest yield in cultivar L-49 (Sardar) (36.65 k year $^{-1}$ ) followed by Chittidar (35.3 $\left.\mathrm{k} \mathrm{year}^{-1}\right)$ and Allahabad Safeda (34.18 k year ${ }^{-1}$ ) under Tripura condition. Aulakh (2005) who recorded maximum yield in cultivar L-49 $\left(75.34 \mathrm{k} \mathrm{tree}^{-1}\right)$ under the arid irrigated conditions of Punjab. The variation in fruit yield may be attributed by many factors like variety, soil conditions, climate, elevation and cultural practices.

\section{Conclusion}

On the basis of overall performance, it may be concluded that the cultivar L-49 (Sardar Guava) has been found best suitable for commercial cultivation in subtropical condition of Himachal Pradesh.

\section{References}

Anonymous, 2014. Area and Production under fruit crops. Database Director of Horticulture, H.P.

Aulakh, P.S., 2005. Performance of different guava cultivars under the arid irrigation conditions of Punjab. Progressive Horticulture 37, 328-330.

Dhaliwal, G.S., Dhillon, S.K., 2003. Effect of tree size on physico-chemical characteristics of fruits of guava $\mathrm{Cv}$. Sardar. Indian Journal of Horticulture 60(4), 312-317.

Dhaliwal, H.S., Gupta Rachana, 2003. Effect of tree size on physico-chemical characteristics of fruits of guava $\mathrm{Cv}$. Sardar. Indian Journal of Horticulture 60, 312-317.

Dubey, P.S., Hoda, M.N., Singh, S., 2002. Studies on growth behaviour of guava germplasm under Sabour conditions for rainy season fruiting. Indian Journal of Horticulture $57,326-328$.

Marak, J.K., Mukunda, G.K., 2007. A promising progeny of Apple Colour guava from Bangalore. Acta Horticulturae
735, 105-108.

NHB, 2014. Horticulture Production Data Book. National Horticulture Board Ministry of Agriculture, Govt. of India, New Delhi.

Ojha, A.P., Tiwari, J.P., Mishra, K.K., 1985. Studies on growth, flowering and yield of guava (Psidium guajava L.) cultivars under Tarai conditions of UP. Progressive Horticulture 17, 13-15.

Patel, R.K., Yadav, D.S., Singh, A., Yadav, R.M., 2011. Performance of Patch Budding on Different Cultivars/ Hybrids of Guava under Mid Hills of Meghalaya. Acta Horticulturae 735, 182-189.

Reddy, N.N., Gangopadhyay, K.K., Rai, M., Kumar, R., 1999. Evaluation of Guava cultivars under rainfed subhumid region of Chhotanagpur plateu. Indian Journal of Horticulture 56 (2), 135-140.

Risterucci, A.M., Duval, M.F., Rohde, W., Billotte, N., 2005. Isolation and characterization of microsatellite loci from Psidium guajava L. Molecular Ecology Notes 5, 745-748.

Sharma, S., Sehrawat, S.K., Saran, P.L., 2011. Comparative performance of superior guava genotypes: flowering and fruit set. Indian Journal of Horticulture 68, 193-196.

Singh, I.P., 2003. Performance of different guava (Psidium guajava L.) cultivars under Tripura climatic conditions. Progressive Horticulture 35 (1), 55-58.

Singh, R., Singh, N., Patidar, R., Gurjar, P.S., Tripathi, S., 2011. Performance of guava (Psidium guajava L.) varieties under Vindhya region of Madhya Pradesh. Life Science Bulletin 8, 61-62.

Singh, S., 2002. Evaluation of guava germplasm under Sabour (Bihar) conditions. Indian Journal of Agricultural Sciences 72, 393-395.

Srivastava, R.P., Srivastava, R.K., 1965. Physico-chemical studies on Safeda, Allahabad and Red Fleshed guava. Punjab Horticulture Journal 5, 12-15.

Westwood, M.N., 1993. Temperate Zone Pomology, Timber Press, Portland, Oregaon. 223p. 